University of Nebraska - Lincoln

DigitalCommons@University of Nebraska - Lincoln

Summer 2011

\title{
Long-Term Groundwater Monitoring Results at Large, Sudden Denatured Ethanol Releases
}

\author{
Roy F. Spalding \\ University of Nebraska - Lincoln, rspalding1@unl.edu \\ Mark A. Toso \\ Minnesota Pollution Control Agency \\ Mary Exner Spalding \\ University of Nebraska-Lincoln, mspalding1@unl.edu \\ Gregory Hattan \\ Kansas Department of Health and the Environment, Topeka, KS \\ Tom M. Higgins \\ Minnesota Pollution Control Agency \\ See next page for additional authors
}

Follow this and additional works at: https://digitalcommons.unl.edu/natrespapers

Part of the Natural Resources and Conservation Commons

Spalding, Roy F.; Toso, Mark A.; Exner Spalding, Mary; Hattan, Gregory; Higgins, Tom M.; Sekely, Adam C.; and Jensen, Shane D., "Long-Term Groundwater Monitoring Results at Large, Sudden Denatured Ethanol Releases" (2011). Papers in Natural Resources. 328.

https://digitalcommons.unl.edu/natrespapers/328

This Article is brought to you for free and open access by the Natural Resources, School of at DigitalCommons@University of Nebraska - Lincoln. It has been accepted for inclusion in Papers in Natural Resources by an authorized administrator of DigitalCommons@University of Nebraska - Lincoln. 


\section{Authors}

Roy F. Spalding, Mark A. Toso, Mary Exner Spalding, Gregory Hattan, Tom M. Higgins, Adam C. Sekely, and Shane D. Jensen 


\title{
Long-Term Groundwater Monitoring Results at Large, Sudden Denatured Ethanol Releases
}

\author{
Roy F. Spalding, Mark A. Toso, Mary E. Exner, Gregory Hattan, \\ Tom M. Higgins, Adam C. Sekely, and Shane D. Jensen
}

\begin{abstract}
Hundreds of groundwater samples were collected at E95 (95\% ethanol, 5\% gasoline) train derailment spills in Balaton and Cambria, Minnesota and South Hutchinson, Kansas. Most samples were analyzed for benzene, toluene, ethylbenzene, and xylenes (BTEX), ethanol, methane, acetate, terminal electron acceptors, and field parameters. At each site, maximum groundwater ethanol concentrations at percent levels were restricted to the release area and downgradient ethanol transport was not detected. A shallow, anaerobic groundwater zone characterized by the absence of dissolved oxygen, low nitrate (less than $1 \mathrm{mg} \mathrm{N} / \mathrm{L}$ ), high Fe+2, and high dissolved methane (more than 10,000 $\mu \mathrm{g} / \mathrm{L}$ ) and BTEX formed and spread downgradient from each release area. BTEX appeared to be persistent. Methane appeared to be generated within the capillary fringe and very shallow groundwater and migrate laterally. Methane's high oxygen demand promotes anaerobic conditions within the shallow groundwater. Estimated and measured methane soil gas concentrations exceeded the lower explosive limit. Long-term monitoring at South Hutchinson and Cambria using 1 to 5 -foot $(0.3$ to $1.5 \mathrm{~m}$ ) well screens straddling the capillary fringe and the shallow water table effectively demonstrated the presence of high ethanol ( 1\%) and benzene (more than $250 \mu \mathrm{g} / \mathrm{L}$ ) concentrations 5 years after the release. The wells appear impacted by long-term ethanol inputs from the vadose zone where ethanol has persisted for years after the initial release. Toxicity, volatile fatty acids, excess hydrogen production, and/or exudate coatings could be responsible for ethanol's preservation. High acetate and hydrogen concentrations at South Hutchinson indicated that fermentation was actively occurring in the very shallow groundwater and/or in the lower capillary fringe. Shortscreened ( 1 to 5 feet; 0.3 to $1.5 \mathrm{~m}$ ) nested wells were pivotal to improving our understanding of ethanol's behavior.
\end{abstract}

\section{Introduction}

Government mandates have rapidly increased the use of ethanol-blended gasoline (mostly E10) throughout the United States. Greater demand likely will occur with the recent approval of E15 by the USEPA and state mandates to increase ethanol use. Twelve states have enacted biofuel mandates with Minnesota's requirement of $20 \%$ ethanol in all gasoline by 2013 being the most ambitious (Pew Center 2010). With the increased production, concerns about potential adverse environmental impacts caused by accidental releases during transport and storage have arisen. The impact of ethanol-blended gasoline releases from aboveand below ground storage tanks on shallow groundwater quality is not fully understood. As the conceptual models of gasoline transport to groundwater are similar to those of ethanol-blended gasoline, one would predict plumes of the more soluble constituents such as ethanol and BTEX (benzene, toluene, ethylbenzene, and xylene) to move downgradient from the source zone.
Both a controlled injection experiment (Zhang et al. 2006) and a field investigation (Buscheck et al. 2001) of an E95 spill showed that ethanol is transported horizontally with groundwater from the source zone at a rate corresponding to the rate of groundwater flow. Because ethanol rapidly consumes oxygen, it may accelerate the depletion of dissolved oxygen and other terminal electron acceptors at the leading edge of a groundwater plume and cause it to become anaerobic (Molson et al. 2002). Concern for enhanced persistence of benzene and the resultant longer plumes predicted by groundwater models have been expressed by Heermann and Powers (1998), Powers et al. (2001), and Deeb et al. (2002). On the basis of the results of field and laboratory studies, Alvarez and Vogel (1995), Corseuil et al. (1998), Rao et al. (1997), and Ruiz-Aguilar et al. (2003) warned that ethanol-containing gasoline would decrease the aerobic degradation rates of benzene and increase plume lengths. In addition to decreasing biodegradation, ethanol's presence would limit the retardation of benzene on aquifer solids (Powers et al. 2001). 
To better predict the fate of benzene at gasohol (E10) releases, Molson et al. (2002) and McNab et al. (1999) developed models that included biodegradation parameters. Their results suggested that the benzene plume from an E10 release would be elongated in comparison to the plume from a gasoline release. There was no field verification of these models.

Almost simultaneously with the postulation of benzene plume elongation, McDowell et al. (2003) and McDowell and Powers (2003) reported the results of benchtop visualization experiments in which important behavioral differences were found in the vadose zone transport of gasoline, E10, and E95. They showed that the vertical flow of isooctane with $10 \%$ ethanol (E10) was faster than the vertical flow of neat isooctane. They also showed that in no-flow aquarium-like tanks E95 was vertically transported to the capillary fringe where it tended to accumulate, and that ethanol- induced reduction in surface tension caused a significant collapse in the height of the capillary fringe. The majority of the E95 accumulated in the top of the capillary fringe and did not extend to the water table. Demonstrations using sand tanks equipped with flowing groundwater added further confirmation that near the water table ethanolblended gasoline behaved differently than gasoline (Stafford 2007). One of the best visualizations of behavioral differences in the two fuels occurred in Stafford's sand tank experiments comparing the dispersal of equal volumes of a surrogate light nonaqueous phase liquid (LNAPL; benzene, toluene, m-xylene, 1,2,4- trimethylbenzene and either $n$ - or iso-octane with weighted fractions of BTX similar to those found in gasoline) and E95 released at the water table. LNAPL sagged significantly below the water table, whereas E95 tended to rise to the top of the capillary fringe and spread longitudinally. The reduced height of the capillary fringe reduced the pore water volume for dilution of the ethanol (Stafford 2007) which may induce higher contaminant concentrations and more horizontal spreading. Supplementary pilot-scale release studies showed that highly concentrated ethanol actually migrated horizontally in a thin layer within the capillary zone and only small amounts entered the saturated zone until drawn in from outflow wells (Cápiro et al. 2007; Stafford et al. 2009). These physical model studies indicate that early groundwater simulation models lack potentially vital information on the complexities of ethanol transport in the vadose zone.

The objective of this long-term study was to elucidate the impact that large (more than 20,000 gallon; more than 75,000 L) E95 releases have on groundwater and soil quality. The unavailability of sites to study controlled releases necessitated that field site selection be opportunistic. Ethanol, BTEX, degradates, and redox indicators were monitored in groundwater at three derailment sites and soil methane at one site for as long as 6 years. Monitoring was overseen by state regulatory agencies and conducted using industrial and leaking underground storage tank site procedures. Additional monitoring improvements were made at all sites although the effort did not approach the sophistication commonly employed by researchers at controlled injection sites in the United States and Canada.

\section{Study Design}

Initially the study design followed normal monitoring well installation for leaky underground storage tank investigations. This included the installation of wells with either 10- or 20-foot ( 3 or $6 \mathrm{~m}$ ) screens upgradient, downgradient, and within the source zone to monitor plumes moving out of the source zone. An ethanol plume, however, was not identified at any of the three sites. These early results instigated the installation of shorter screened ( 1 to 5 feet) $(0.3$ to $1.5 \mathrm{~m}$ ) wells to monitor groundwater at the capillary fringe/water table interface.

The field sites are near the towns of Balaton and Cambria in southwest and south-central Minnesota, respectively, and in South Hutchinson in south-central Kansas (Figure 1). Details of each site's E95 release and general site hydrogeology are presented in Table 1.

\section{Balaton, Minnesota}

The earliest derailment occurred at the Balaton site which is about 400 feet $(122 \mathrm{~m})$ south of Lake Yankton, a large recreational and fishing lake (Figure 2). Approximately 40,000 gallons (151,200 L) of E95 and soybean oil were released on July 28, 2004 (Pinnacle Engineering 2004a). At the time of the spill, depth to groundwater varied with the topography from about 5 feet $(1.5 \mathrm{~m})$ beneath the ditch to 11.5 feet $(3.5 \mathrm{~m})$ on the east side of the grain elevator. Clay berms effectively contained the ethanol and soybean oil and protected Lake Yankton from a fish kill. Ponded product was pumped into tanker trucks and later remediated in highly aerated ponds at a local wastewater treatment facility. Contaminated soil was excavated and land applied and the ditch partially filled with clean soil. Soil texture was highly variable in the top 4 feet $(1.2 \mathrm{~m})$ and ranged from silty clay to silty fine sand. Below 4 feet $(1.2 \mathrm{~m})$, the sediments graded to sand and sand and gravel with an occasional silty lens (Pinnacle Engineering 2004b).

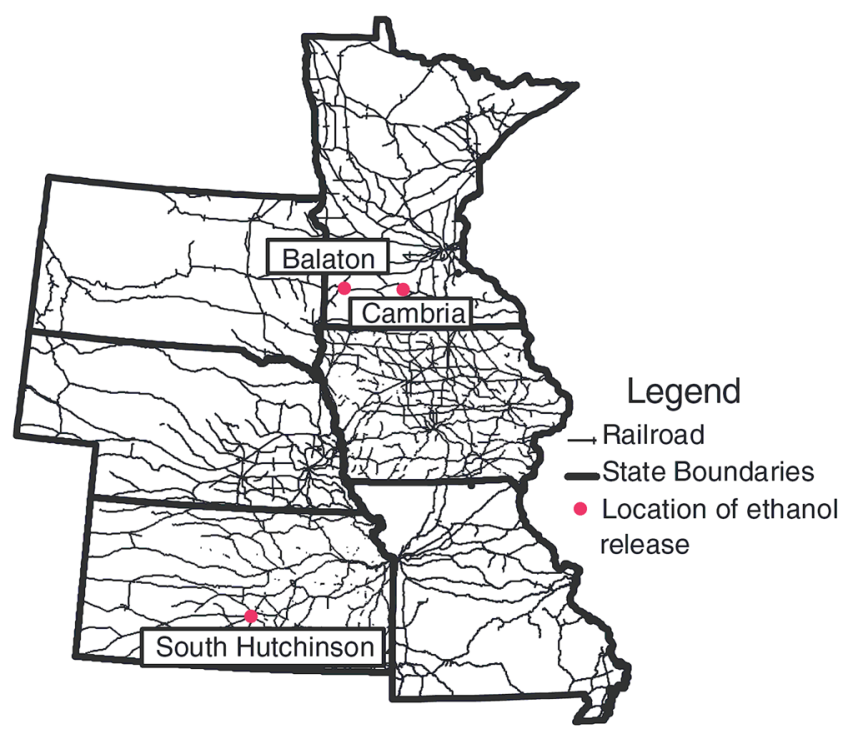

Figure 1. Locations of three investigated E95 releases in Minnesota and Kansas. 
Table 1. Study Site Characteristics

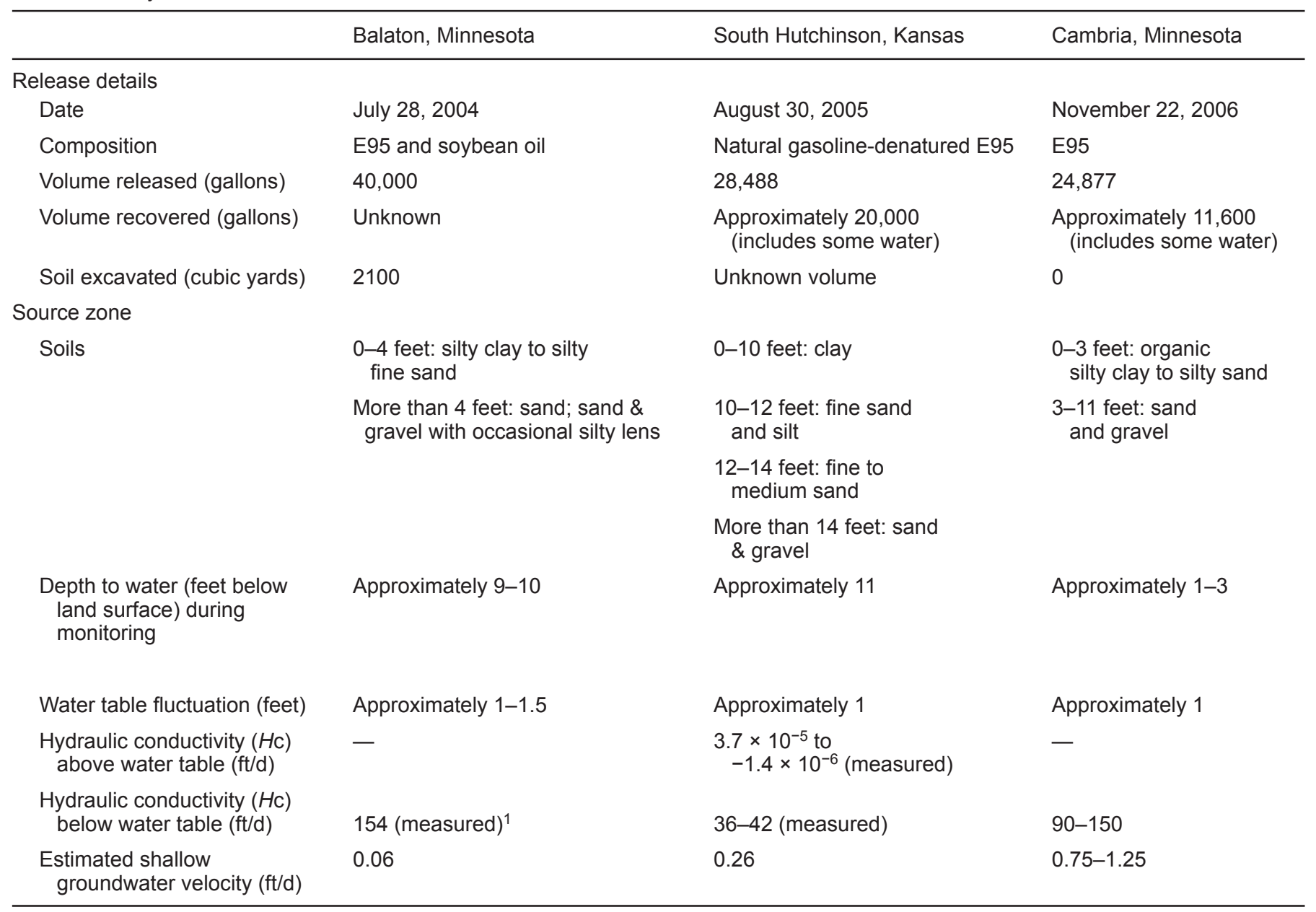

1. Pinnacle Engineering 2006.

Ethanol concentrations as high as $2.9 \%$ were measured in the shallow groundwater at 3 of 11 Geoprobe ${ }^{\circledR}$ (Geoprobe Systems, Salina, Kansas) borings in September 2004 (Pinnacle Engineering 2004b). Four 2-inch (5.1 $\mathrm{cm})$ polyvinyl chloride (PVC) monitoring wells (MW-1 to MW-4) with 10-foot (3 m), 10-slot PVC screens set to intercept the water table and allow for water table fluctuations were installed in late March 2005. Monitoring wells MW-5 to MW-11 were installed after additional Geoprobe ${ }^{\circledR}$ borings were completed in summer 2007. With the exceptions of MW-7D and MW-9 which have one 5-foot $(1.5 \mathrm{~m}), 10$-slot screen, wells MW-5 through MW-11 each have one 7-foot $(2.1 \mathrm{~m})$, 10-slot screen. Some of these well screens straddle the water table; others are always below the water table. Wells MW-12 and MW-13, each with one 5-foot $(1.5 \mathrm{~m}), 10$-slot screen, were installed between the source zone and Lake Yankton in summer 2008. The natural ground water gradient is to the east-northeast and almost flat.

\section{South Hutchinson, Kansas}

On August 30, 2005 two tank cars derailed on a railroad spur in South Hutchinson, Kansas. One car split open, releasing 28,488 gallons $(107,685 \mathrm{~L})$ of E95 on the east side of the track (Figure 3 ). The denaturant was confirmed to be natural gasoline from a nearby refinery in McPherson, Kansas. Ethanol flowed into a northsouth ditch along the east side of the track. The ditch contained a few inches of water at the time of the release. Approximately 20,000 gallons (75,600 L) of water and ethanol from several sumps dug in the ditch were pumped into a separator. Most of the 8000 residual gallons $(30,240 \mathrm{~L})$ seeped into the ground while a small quantity flowed north into a shallow, quarter-acre (1000 $\mathrm{m}^{2}$ ) pond and subsequently into a lake on the west side of the track before being contained by a berm installed by emergency response personnel. Approximately 150 catfish and carp in the lake were killed. Strong fumes necessitated the evacuation of nearby homes, a mental health facility, and a middle school. The site, in the Arkansas River valley, is topographically flat and is underlain by the Equus Beds aquifer, which is characterized by highly productive sand and gravel. Groundwater flow is to the east-northeast.

Two months after the spill, groundwater samples were collected at six sites in the spill area using a Geoprobe ${ }^{\circledR}$ model 66DT. A continuous sediment core recovered from the source zone in November 2005 was tested for hydraulic conductivity (Table 1). The gravimetric water content was approximately $20 \%$ in the clays, and the sediments 


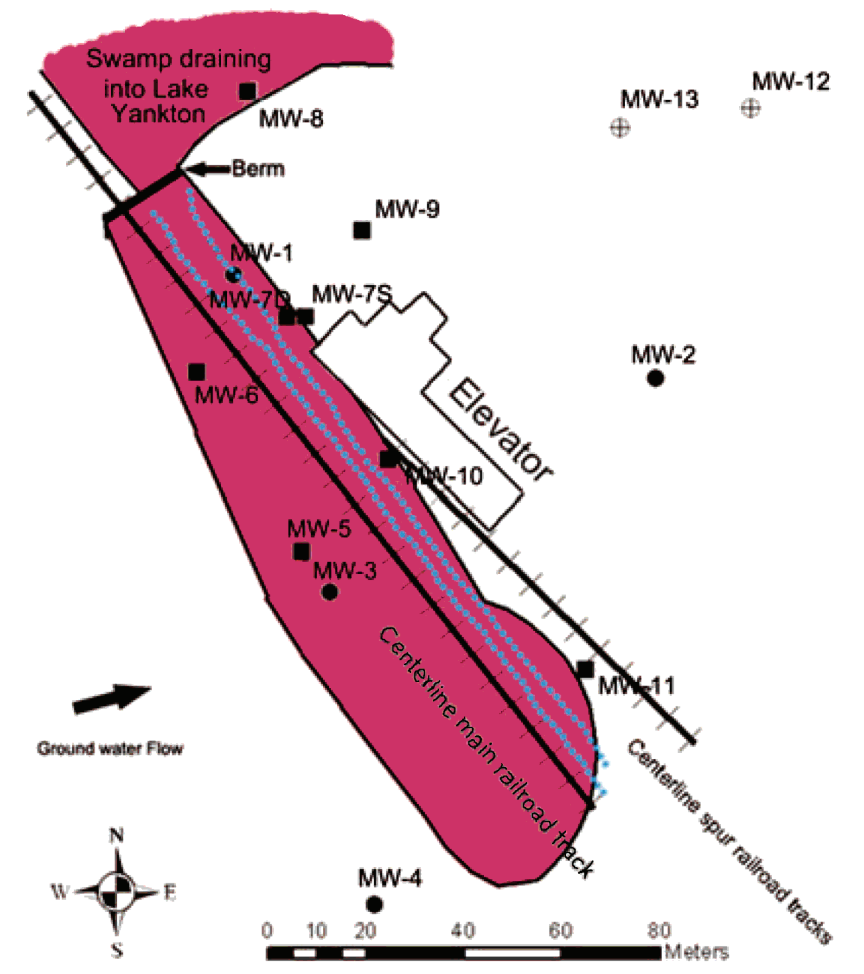

Figure 2. Balaton, Minnesota site. Area of E95 release is shown in pink; ditch is outlined in blue. Single monitoring well with: $\bullet 10$-foot screen installed in March 2005; 7 -foot screen installed in summer 2007 except MW-7D and MW-9 which have 5-foot screen; $\oplus 5$-foot screen installed in summer 2008. Schematic is derived from Pinnacle Engineering (2004a, 2004b) reports.

were very moist above the water table in the transition from clays to fine sands between 9 and 11 feet (2.7 to 3.3 $\mathrm{m})$. During probing, well construction, and coring, many of the deeper sediments contained a black slime and some also had a discernable ethanol odor. These black slimes were remarkably similar to those reported at ethanol injection sites by one of the authors.

Low ethanol concentrations (less than 5 to $740 \mu \mathrm{g} / \mathrm{L}$ ) were detected in Geoprobe ${ }^{\circledR}$ sampling at the water table and suggested that the leading edge of the contamination had reached or was near the water table within 2 months of the release. In late July 2006, ten 2-inch (5.1$\mathrm{cm}$ ) PVC wells were installed using a hollow stem auger at and near the release point and along the drainage ditch that empties into the pond. Single wells had 20 feet $(6 \mathrm{~m})$ of 10 -slot screen placed at the water table and were designed to intercept a thick, dissolved phase ethanol plume emanating from the release. The shallow, medium, and deep wells in nests MW- 5 and MW- 6 were screened from 11 to 16 feet ( 3.3 to $4.9 \mathrm{~m}$ ), 18 to 23 feet ( 5.5 to $7.0 \mathrm{~m}$ ), and 25 to 30 feet $(7.6$ to $9.1 \mathrm{~m}$ ) below land surface (bls), respectively. Contaminant concentrations, however, were low; most likely the result of screen dilution. For that reason, an additional eleven 2-inch (5.1 $\mathrm{cm})$ PVC wells screened from 1 foot $(0.3 \mathrm{~m})$ above to 4 feet $(1.2 \mathrm{~m})$ below the water table were installed to intercept LNAPL and any footprint of ethanol degradation occurring in the very shallow groundwater and/or the vadose zone. Designated by "SW" in Figure 3, the wells were installed in September 2007.

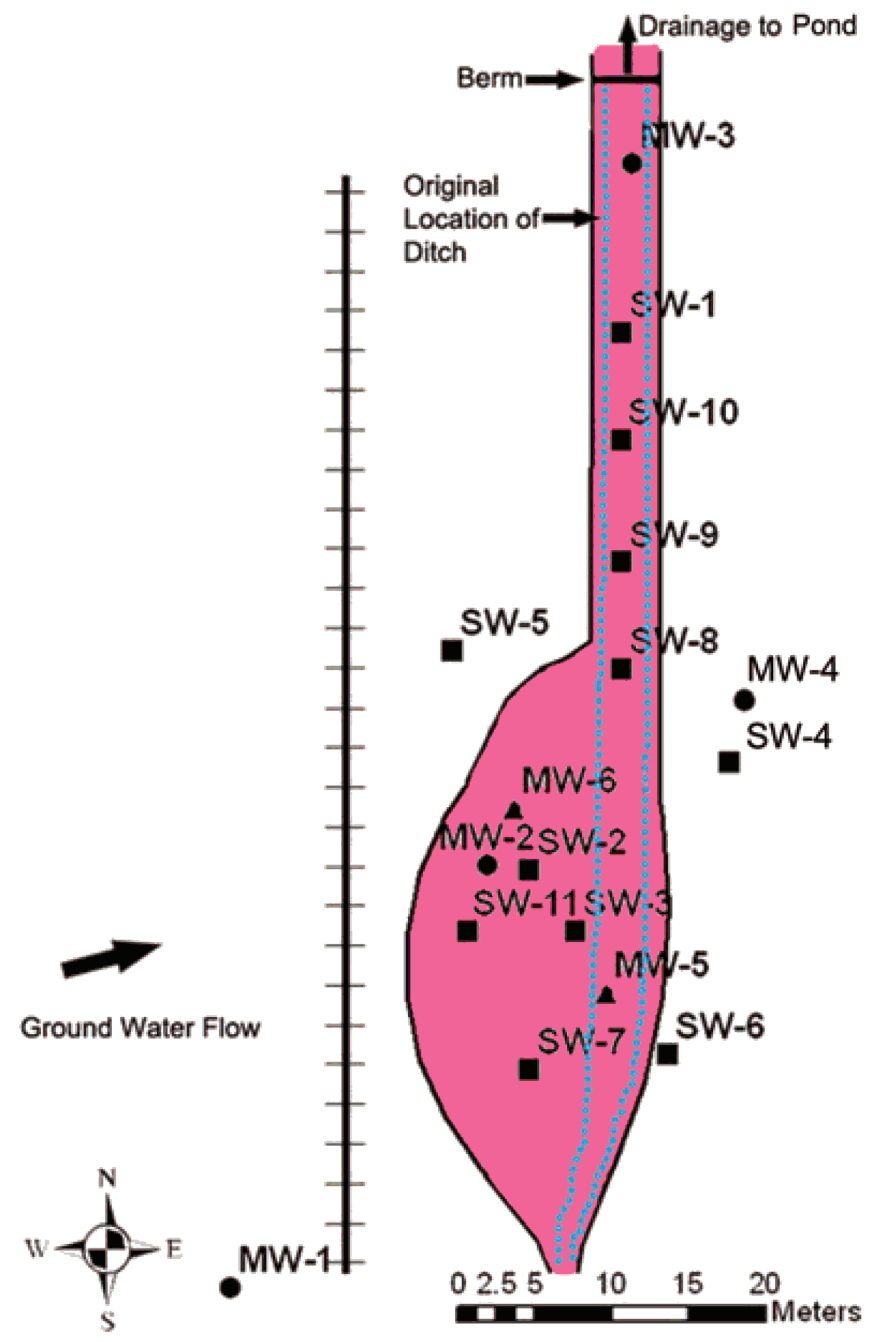

Figure 3. South Hutchinson, Kansas site. Area of E95 release is shown in pink; ditch is outlined in blue. - Single monitoring well with 20 -foot screen and $\boldsymbol{\Delta}$ well nests with 5 -foot screened wells installed in July 2006; single monitoring well with 5 -foot screen installed in September 2007. Delineation of the source area is based on information provided by the emergency response team.

\section{Cambria, Minnesota}

The third investigated release occurred at Cambria, Minnesota where in late November 2006, 24,877 gallons $(94,035 \mathrm{~L})$ of E95 were released after several tank cars derailed (Pinnacle Engineering 2007). The railcars tumbled about 15 feet $(4.6 \mathrm{~m})$ from the raised track bed to a low area on the south side of the track (Figure 4). A car that remained on the trestle leaked about 500 gallons $(1890 \mathrm{~L})$ of E95 approximately 210 feet $(\sim 64 \mathrm{~m})$ northwest of the principal source zone near MWC-8. About 13,000 gallons $(49,140 \mathrm{~L})$ remained after the removal of ponded E95. No soil excavation occurred in the two source areas; however, soils were disturbed during release containment.

Depth to water varied from about 1 to 3 feet ( 0.3 to $0.9 \mathrm{~m}$ ) in the principal source zone, which is a ditch on the south side of the track, to about 10 to 12 feet ( 3 to 3.6 $\mathrm{m})$ on a hill south of the source zone. Groundwater flow is eastnortheast toward the Minnesota River. Soils are primarily silty sand flood plain deposits. 


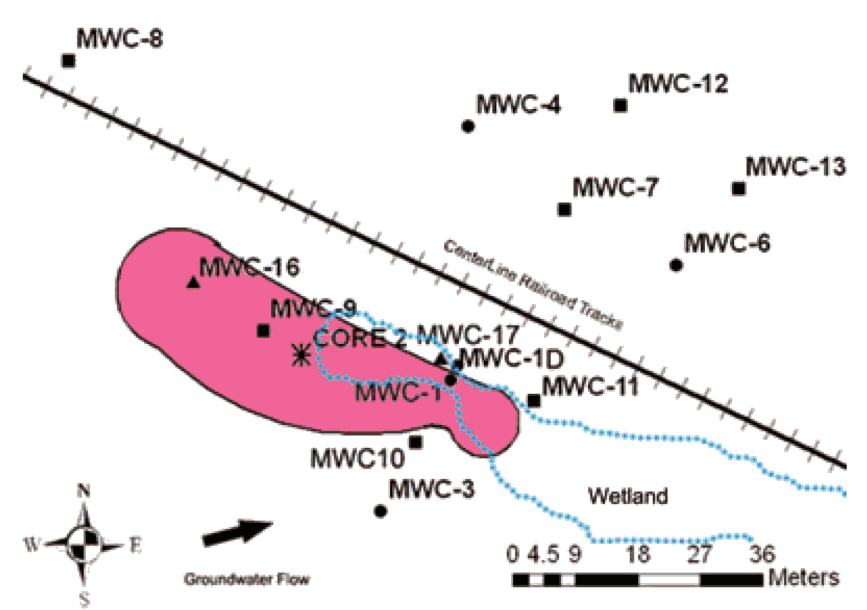

Figure 4. Cambria, Minnesota site. Area of E95 release is shown in pink; wetland is outlined in blue. Single monitoring well with: 1 10-foot screen installed in December 2006 and 5-foot screen (MWC-6) installed in January 2007; 5 -foot screen installed in July 2007. A Well nests with 1-foot screened wells installed in November 2008. Schematic is derived from Pinnacle Engineering (2007) report.

The Cambria site initially was monitored with 2-inch $(5.1 \mathrm{~cm})$ diameter PVC wells with 10-foot $(3 \mathrm{~m})$ screens. Screens in shallow wells MWC-1, MWC-3, and MWC-4 were placed at the water table. Deep well MWC-1D in the source zone was completed to 40 feet $(12 \mathrm{~m})$. A shallow well (MWC-6) with a 5-foot $(1.5 \mathrm{~m})$ screen was installed in January 2007. Seven additional shallow wells (MWC-7 to MWC-13) with 5-foot (1.5 m) screens that intercept the water table were installed in July 2007 to increase the coverage of both the principal source area and the downgradient area on the north side of the track. Two 3-well nests (MWC-16, MWC-17) were installed in the source zone in November 2008. Each 1-inch $(2.5 \mathrm{~cm})$ well has a 1 -foot $(0.3 \mathrm{~m})$ pre-packed well screen. In each nest the shallowest screen was set less than 1 foot $(0.3 \mathrm{~m})$ below the water table and in each progressively deeper well the screen was set 3 feet $(0.9 \mathrm{~m})$ deeper. These wells were sampled during 2009 and 2010.

\section{Methodologies}

\section{Sampling}

Depth to water was measured with a Solinst ${ }^{\circledR}$ (Solinist Canada, Georgetown, Ontario, Canada) model 101 water level meter prior to well purging. Wells at Balaton and Cambria were purged using a Whale ${ }^{\circledR}$ (Munster Simms Engineering, Bangor, Northern Ireland) minipurging pump that was decontaminated between wells. Samples were collected when $\mathrm{pH}$, temperature, redox potential, conductivity, and dissolved oxygen stabilized. Masterflex ${ }^{\circledR}$ (Cole-Palmer Instrument Company, Vernon Hills, Illinois) peristaltic pumps with dedicated tubing were used to sample nested wells MWC-16 and MWC-17. At South Hutchinson Grundfos ${ }^{\circledR}$ (Bjerringbro, Denmark) submersible, Whale ${ }^{\circledR}$ minipurging, or Masterflex ${ }^{\circledR}$ (ColePalmer Instrument Company, Vernon Hills, Illinois) peristaltic pumps were used for purging and samples were collected after three or more casing volumes were removed. Initial checks found that $\mathrm{pH}$ and conductivity stabilized after three casing volumes were removed.
At all three sites samples for ethanol and BTEX analysis were collected in pre-acidified 40-mL VOAs capped with Teflon-lined septa. Methane sampling followed the procedure of Kampbell and Vandegrift (1998). Samples were collected in triplicate in $27-\mathrm{mL}$ serum vials. The vials were completely filled, acidified with $0.5 \mathrm{M} \mathrm{HCl}$, capped with crimp top seals having Teflon-faced rubber septa, checked for bubbles and refilled if bubbles were present. Samples for acetate and anion analyses were collected in 125$\mathrm{mL}$ high density polyethylene screw-cap bottles. Cores were collected in a lined macrocore barrel using a truckmounted Geoprobe ${ }^{\circledR}$; cut into 2-foot $(0.6 \mathrm{~m})$ sections; capped and labeled. All water and core samples were kept on ice in coolers until received by the laboratory.

In 2009 and 2010 South Hutchinson monitoring wells with elevated ethanol and/or dissolved methane were sampled for hydrogen using peristaltic pumps (Chapelle et al. 1997) with dedicated tubing and a Microseeps ${ }^{\circledR}$ (Microseeps, Inc., Pittsburgh, Pennsylvania) gas stripping cell following the procedure of McInnes and Kampbell (2003). Briefly, water was pumped through the gas stripping cell at approximately $300 \mathrm{~mL} / \mathrm{min}$. After equilibrium was reached (15 to $20 \mathrm{~min}$ ), a 10-mL sample was removed from the headspace and injected into a crimpcapped $27-\mathrm{mL}$ serum vial filled with ultrapure $\mathrm{N}_{2}$. The hydrogen samples were not cooled during transport.

\section{Analytical}

Ethanol and BTEX in water and sediment samples from the South Hutchinson site and in sediment from the Cambria site were measured by Kiff Analytical, Davis, California using the purge and trap gas chromatography/mass spectrometry (GC/MS) USEPA method 8260B. Kiff Analytical has enhanced ethanol detection limits by introducing a heated purge unit. Their method reporting limit for ethanol in water is $5 \mu \mathrm{g} / \mathrm{L}$. Sediment samples were analyzed by placing a 5-g aliquot of soil and $10 \mathrm{~mL}$ of distilled, de-ionized water in a purge tube prior to analysis. Before the Minnesota Pollution Control Agency and University of Nebraska assumed monitoring at the Cambria and Balaton sites, ethanol and BTEX in groundwater were analyzed at Minnesota Valley Testing Laboratories, Inc. Their ethanol method reporting limit was 100,000 $\mu \mathrm{g} / \mathrm{L}$. Since June 2007, BTEX and ethanol in some water samples were analyzed by Kiff Analytical; but, most of the analyses were done by the Minnesota Department of Health Laboratory using USEPA method 8260B. Their method reporting limit for ethanol is $100 \mu \mathrm{g} / \mathrm{L}$.

All methane samples were analyzed by GC with a flame ionization detector (Kampbell and Vandegrift 1998) at the University of Nebraska-Lincoln's (UNL) Department of Agronomy and Horticulture soil gas laboratory. The method detection limit is $0.6 \mu \mathrm{g} / \mathrm{L}$.

Nitrate, nitrite, and sulfate were analyzed at UNL by anion chromatography following USEPA method 300. Acetate was measured using a Dionex ${ }^{\circledR}$ (Dionex Corporation, Sunnyvale, California) DX-100 ion chromatograph with an $\operatorname{IonPac}^{\circledR}$ (Dionex) AS14A column $(4 \times 250 \mathrm{~mm})$ and a conductivity detector. Formate, another volatile fatty acid (VFA), elutes on the acetate tail; consequently, the reported acetate concentrations may include some 
formate. Dissolved iron was measured using a CHEMetrics $^{\circledR}$ (CHEMetrics, Inc., Calverton, Virginia) visual kit employing the colorimetric phenanthroline method with a method reporting limit of $0.05 \mathrm{mg} / \mathrm{L}$. Dissolved oxygen was measured in the field by the iodometric method with the azide modification (APHA 1998).

Hydrogen was analyzed using a Trace Analytical RGA3 Reduction Gas Analyzer equipped with a 1-mL sample loop and a $51 \times 1 / 8$-inch $(1.3 \mathrm{~m} \times 3.2 \mathrm{~mm})$ MS13X Porapak column. The carrier gas was ultrapure $\mathrm{N}_{2}$ set at a flow rate of $20 \mathrm{~mL} / \mathrm{min}$. Hydrogen is oxidized in a heated mercuric oxide reactor bed and the mercury vapor, which is directly proportional to the hydrogen oxidized, is measured by an ultraviolet photometer detector. The retention time is about $0.5 \mathrm{~min}$.

Soil gas was measured at Balaton using permanent soil gas vapor points installed in nests similar to those illustrated in Interstate Technology and Regulatory Council (2007). Soil methane was withdrawn from the points and measured in the field using a LANDTEC GEM $^{\circledR}$ (LANDTEC, Colton, California) landfill gas meter and also collected in canisters and measured in the laboratory using USEPA method 3C.

\section{Results and Discussion}

\section{Ethanol}

Initial ethanol concentrations in the groundwater at both Balaton and Cambria were at or near percent levels (Figure 5). Concentrations in the first groundwater samples at South Hutchinson, collected using a Geoprobe ${ }^{\circledR}$, were less than $1 \mathrm{mg} / \mathrm{L}$. Early breakthrough concentrations indicate rapid vertical transport of ethanol to the groundwater. At each site, there was an additional head pressure from 1 to 2 feet $(0.3$ to $0.6 \mathrm{~m})$ of product that had drained into the ditches paralleling the tracks. In tight soils like those at South Hutchinson, E95 transport could be enhanced by macropore flow (Adamski et al. 2005), clay dispersion (Leonard and Jackson 1975), and/ or surfactant-induced flow (Smith and Gillham 1999; Bashir et al. 2008).

High groundwater ethanol concentrations at both Minnesota sites (Figure 5) occurred in source-zone wells. The wells were topographically situated at higiher or slightly higher elevations than the ditches where most of the released ethanol accumulated. Maximum ethanol concentrations in these wells decreased from low percent levels to less than $100 \mathrm{mg} / \mathrm{L}$ in approximately 14 months. The estimated rate of decrease in ethanol in Balaton's MW-1 where quantified concentrations ranged from 41,000 to $2800 \mathrm{mg} / \mathrm{L}$ was approximately $100 \mathrm{mg}$ / $\mathrm{L} / \mathrm{d}$. Reported rates of ethanol decay range from 2.9 $\mathrm{mg} / \mathrm{L} / \mathrm{d}$ (Corseuil et al. 2000) to more than $500 \mathrm{mg} /$ L/d in a sulfate-reducing aquifer (Mackay et al. 2006). The most commonly reported decay rates are 20 to 70 $\mathrm{mg} / \mathrm{L} / \mathrm{d}$ (McDowell et al. 2003; Zhang et al. 2006). The 11-month linear rate of decrease at Balaton was slightly higher than other long-term study rates.

A most interesting observation is that ethanol in low percent concentrations was still present in the groundwater at Cambria in June 2010 and South Hutchinson in July 2010, approximately 4 and 5 years, respectively,

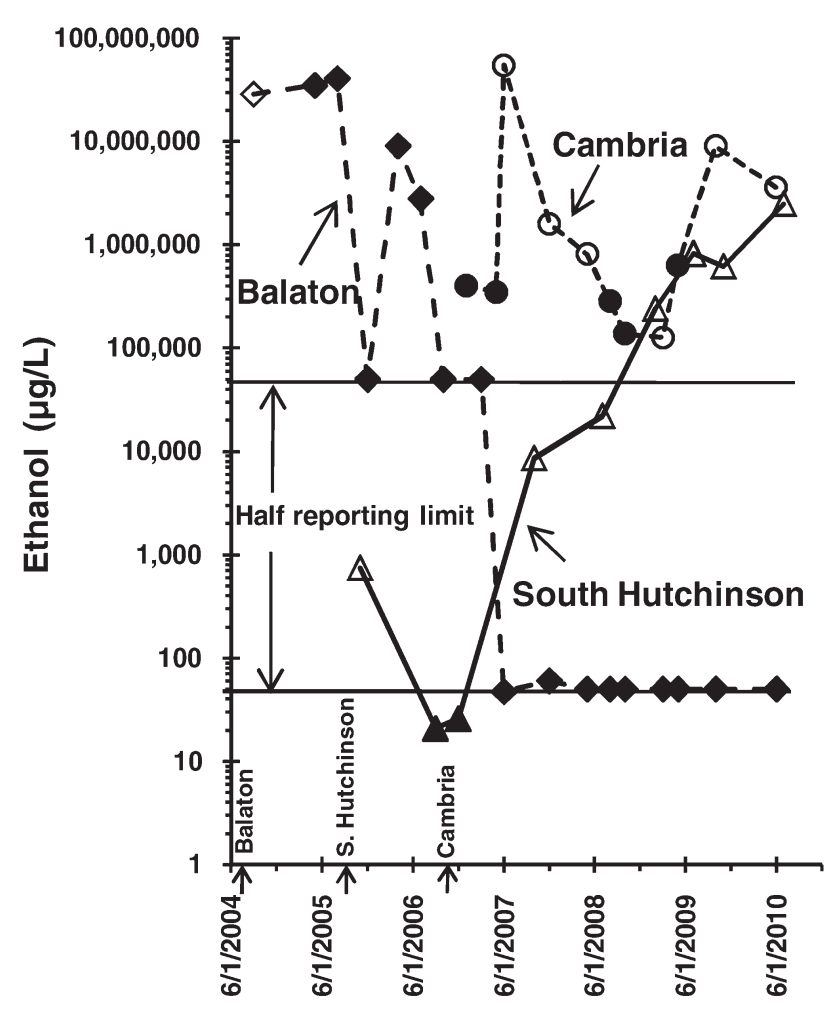

Figure 5. Temporal trend of maximum groundwater ethanol concentrations at the Balaton, Cambria, and South Hutchinson sites. Date of E95 release at each site is indicated on x-axis. Open symbols denote concentrations in wells with short ( $\leq 5$-foot) screens. Half reporting limit concentrations are only for Balaton results.

after its release (Figure 5). Because ethanol has a very short laboratory- derived half-life-an aerobic $t_{1 / 2}$ of hours and an anaerobic $t_{1 / 2}$ of 2 to $10 \mathrm{~d}$ (Energy Institute 2008) - its persistence after 5 years was unexpected. Residual high ethanol concentrations occurred only in short-screened ( $\leq 5$ feet) wells designed to monitor conditions at the water table at Cambria and South Hutchinson. Residual ethanol may remain in the vadose zone and capillary fringe in the source zone at Balaton. The site, however, has a complex flow system and may lack the strategic placement of wells and screens that are necessary for the detection of thin residual ethanol layers at the top of the aquifer.

The stratification of ethanol and related compounds at Cambria's multilevel sampler MWC-16 is depicted in Figure 6 . The ethanol in the shallow well may represent vertical migration from the capillary fringe during water table fluctuations or pumping. The 14 to $17 \mathrm{inch}$ bls ( 35 to $43 \mathrm{~cm}$ ) interval of core 2 (Figure 4) collected in late June 2010 contained $2.1 \%$ ethanol by weight.

Ethanol concentrations at South Hutchinson's SW-11 have steadily increased during the last 3 years to 2500 $\mathrm{mg} / \mathrm{L}$ (Figure 5). During the same time period, ethanol concentrations in nearby SW-7 were four magnitudes lower. The data suggest that at South Hutchinson vertical transport is either delayed by a very fine-textured unsaturated zone or ethanol resides in significant concentrations above the water table in the vadose zone. From the high moisture content observed below 9 feet $(2.7 \mathrm{~m})$ in the continuous core collected in November 


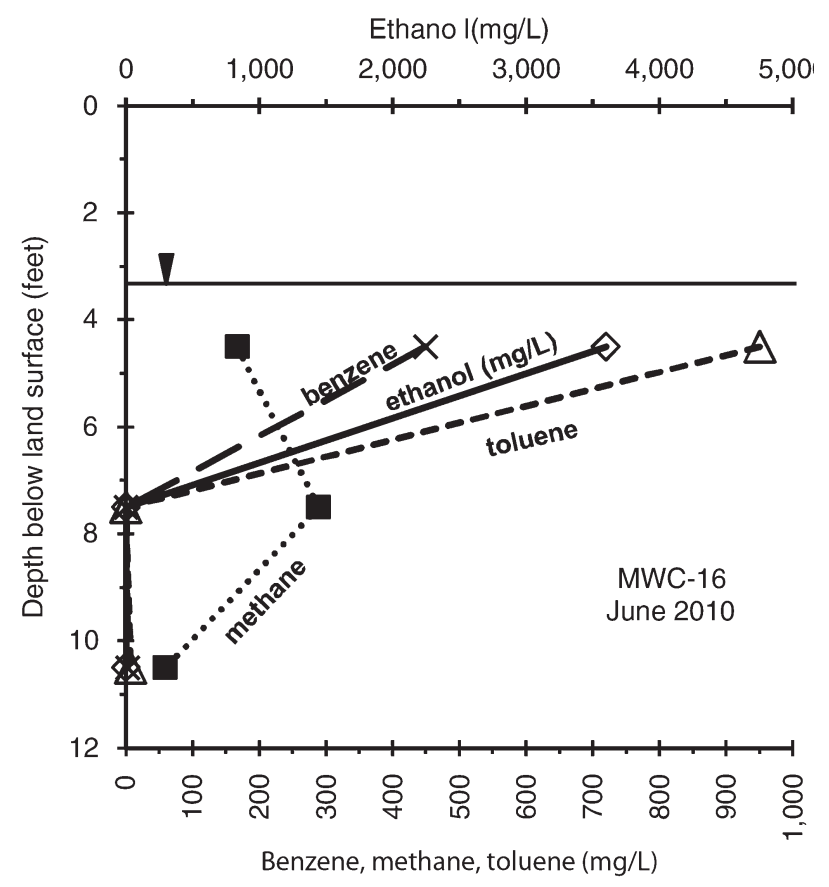

Figure 6. Vertical profiles of dissolved ethanol, benzene, toluene, and methane concentrations at Cambria's well nest MWC-16. Concentration is depicted at the mid-point of each 1 -foot well screen.

2005, the capillary fringe is estimated to be at least 2 feet $(0.6 \mathrm{~m})$ in thickness. In October 2010, cores were collected at four locations in the release area where soils were not excavated during the 2006 emergency response. Significant levels of ethanol (up to $18,000 \mathrm{mg} /$ $\mathrm{kg}$ ) occurred in the soils of three cores. Ethanol at percent levels was present 2 to 8 feet $(0.6$ to $2.4 \mathrm{~m})$ bls in two cores closest to the railroad track. Owing to its high solubility, ethanol is assumed to be in the pore water and with a $20 \pm 1 \%$ measured gravimetric water content and bulk density of $1.1 \mathrm{~g} / \mathrm{cc}$, ethanol concentrations in the core would approach $9 \%$ by volume. These findings indicate that ethanol was not significantly attenuated in the vadose zone and that there will be a continuous source of ethanol to the capillary fringe and shallow groundwater for several more years.

There are several potential hypotheses for ethanol's persistence in the vadose zone. They include ethanol's buoyancy within the capillary fringe, ethanol's toxicity to bacterial proliferation, and concentrated ethanol encapsulation by bacterial exudates. Stafford (2007) has described ethanol's buoyancy as a behavior that drives it above the water table into the partially collapsed capillary fringe. The latest toxicity results indicate that ethanol concentrations more than $6 \%$ are toxic to microbes (Nelson et al. 2010) which is much lower than the $40 \%$ concentration previously reported by Hunt et al. (1997). Ethanol concentrations more than $6 \%$ in the pore water of the vadose zone at the investigated E95 release sites occurred, and toxicity could play an important role in the preservation of ethanol. Bacterial slimes could envelop concentrated ethanol layers within the capillary fringe and shallow groundwater. Bacterial extracellular polymers have long been known to retard mobility and dilution (Vandevivere and Baveye 1992). A black slime con- sisting of bacterial exudates was observed in the lower vadose zone of the source area at all three sites. A similar slime developed during continuous ethanol injections at denitrification research sites in Nebraska and resulted in biofouling of tile slots and injection well screens at the water table and below (Khan and Spalding 2003). Similar biofouling experiences reported by Ghose and Bhadra (1985) and Constantin and Fick (1997) resulted in the substitution of acetate for ethanol as was done by Khan and Spalding (2004). An excessive buildup of VFAs; namely, acetate, could also contribute to ethanol's persistence in the vadose zone. High concentrations of VFAs in landfills led to $\mathrm{pH}$ depression and, subsequently, to lowered rates of meth anogenesis (Mormile et al. 1996).

To date, ethanol in the groundwater at all three sites has been confined to specific wells in the source zone and transport has not been observed within the source zone or downgradient of the source zone. At South Hutchinson and Cambria residual soil ethanol contamination occurred in areas of the source zone which were not excavated. The data appear to demonstrate the importance of soil excavation at E95 release sites. The data suggest that where there are continuous inputs of ethanol to groundwater, the bulk of the ethanol appears to remain in finetextured soils and the capillary fringe. The direct impact of ethanol on groundwater at all three sites has been limited to relatively small areas comprising a few thousand square feet (few hundred square meters) at most.

\section{Benzene}

At all three sites, the ethanol denaturant was gasolinebased and contained BTEX. These compounds were measured in most monitoring wells during the study. Of the four aromatic compounds, benzene receives the greatest attention because as a carcinogen it has a relatively low drinking water maximum contaminant level of $5 \mu \mathrm{g} / \mathrm{L}$. Maximum benzene concentrations in shallow groundwater ranged from 5300 to 3400 to $560 \mu \mathrm{g} / \mathrm{L}$ at Cambria, Balaton, and South Hutchinson, respectively (Figure 7). There is a general temporal trend of lower maximum benzene concentrations at Cambria and Balaton while concentrations at South Hutchinson appear to be increasing. Although the dissolved ethanol and BTEX in the groundwater at each site originated from an E95 source, several samples at each site had relatively high benzene and very low ethanol concentrations. Recent reports suggest that these results could involve differential mobilization of petroleum compounds (BTEX) and ethanol within the capillary fringe. This was demonstrated in visual experiments in which E95 was injected under fluctuating water table conditions (Stafford and Rixey 2011) and in controlled experiments in the Borden aquifer (Freitas et al. 2011). During rising water table conditions, as would be expected when large E95 releases impact the water table, ethanol could be in part diluted to concentrations that no longer promote cosolvency with benzene $(\sim 25 \%)$ (Rixey et al. 2005). This allows mobilization of benzene at increased levels in shallow groundwater while ethanol as suggested by Freitas et al. (2011) would remain partially trapped in lower conductivity regions of the unsaturated zone. A second scenario involves the preferential degradation of ethanol in 


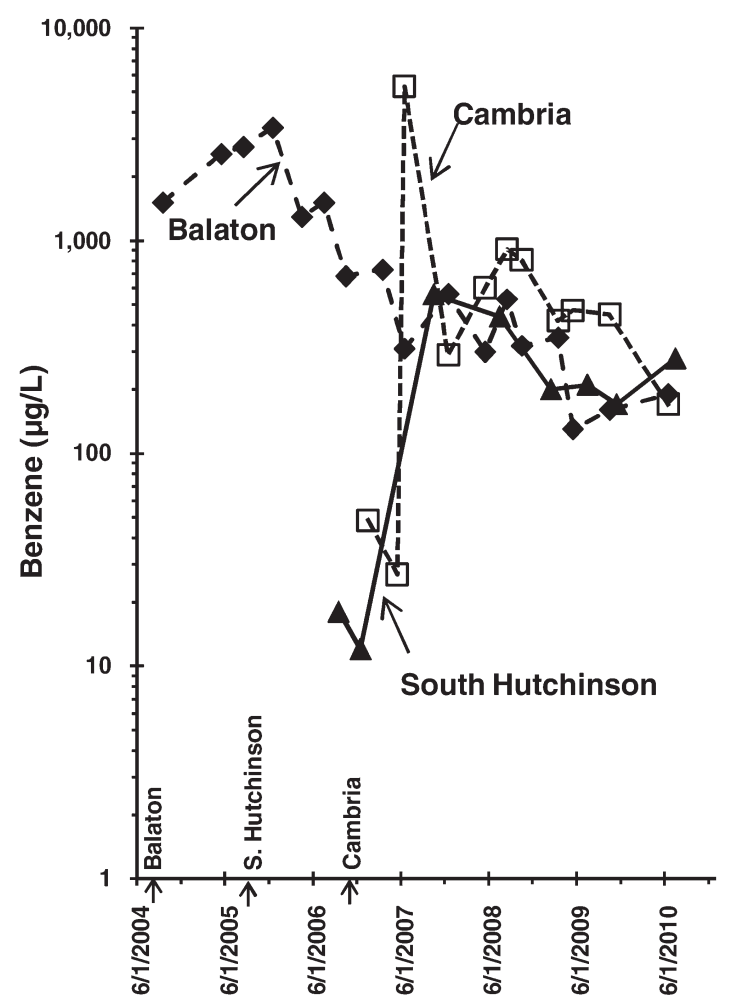

Figure 7. Temporal trend of maximum groundwater benzene concentrations at the Balaton, Cambria, and South Hutchinson sites. Date of E95 release at each site is indicated on $\mathrm{x}$-axis.

anaerobic environments (Corseuil et al. 1998). The anaerobic half-life of benzene is 7.3 years (Lovley 2000), whereas the anaerobic half-life of ethanol is 2 to $10 \mathrm{~d}$ (Energy Institute 2008). Field studies during controlled injections in a sulfate-reducing aquifer at the Vandenberg site also have shown that there is a significant difference in the anaerobic half-lives of ethanol and benzene (Mackay et al. 2006). These behavioral differences result in the preferential distribution of benzene in more source-zone wells than ethanol which would be the expected distribution in shallow groundwater containing the electron donors, acetate and methane. Chen et al. (2008) reported that in wells devoid of ethanol the presence of high levels of electron donor degradates helps stabilize anaerobic conditions and essentially shuts down benzene biodegradation. A comparison of the distribution of benzene and methane, a high oxygen demand molecule, in shallow groundwater at Balaton clearly shows that wells containing benzene contain relatively high methane levels (Figure 8). Although benzene persists in the anaerobic shallow groundwater at these sites, there is no evidence for deep or extensive groundwater contamination downgradient of the source zone.

\section{Redox Indicators}

The monitoring of dissolved oxygen, the terminal electron acceptors nitrate and sulfate, and ferrous iron $\left(\mathrm{Fe}^{+2}\right)$ revealed highly reducing conditions in the shallow groundwater at all three sites. In general, reducing conditions were very stratified with depth indicating that the electron donors are degrading within relatively thin zones at the top of the aquifer. All shallow wells within the source zones generally had low to below detectable dissolved oxygen levels. Low background nitrate concentrations at the Minnesota sites had little impact on ethanol degradation. At South Hutchinson nitrate in the shallow groundwater was depleted as it flowed into the source zone (Figure 9). Upgradient concentrations were slightly below $10 \mathrm{mg} \mathrm{N} / \mathrm{L}$, but it is unlikely they would significantly impact ethanol and/or acetate degradation. Ferrous iron in several source-zone wells was elevated to levels exceeding the maximum 10 $\mathrm{mg} / \mathrm{L}$ field kit response. Elevated $\mathrm{Fe}^{+2}$ levels were always present in SW-2, SW-3, SW-7, SW-11, and first appeared in MW-2, MW-5S, and MW-6S 2 years after the release. Concentrations generally fell to below detection in MW-6M and MW-6D and MW-5M and MW-5D (Figure 9) indicating that $\mathrm{Fe}^{+2}$ levels were highly stratified and that reduction likely occurred at or near the capillary fringe/water table interface. Similarly high ferrous iron concentrations were detected in the source zone at Cambria where sharp ethanol, benzene, and toluene concentration gradients with depth (Figure 6) likely marked the redox front. The electron donors, ethanol and acetate, likely fueled iron reduction in the shallow groundwater and capillary fringe. Corseuil et al. (1998) reported that ethanol's presence in microcosms caused the quick development of anaerobic conditions, increased iron reduction, and produced methanogenic conditions leading to BTEX persisting in the microcosm for $99 \mathrm{~d}$.

\section{Ethanol Degradates}

\section{Acetate}

Many source-zone wells contained significant concentrations of acetate, a VFA formed during the fermentation of ethanol in the following reaction:

$$
\mathrm{CH}_{3} \mathrm{CH}_{2} \mathrm{OH}+\mathrm{H}_{2} \mathrm{O}=\mathrm{CH}_{3} \mathrm{COOH}+2 \mathrm{H}_{2} \text {. }
$$

Although acetate was detected in several sourcezone wells at all three sites, ethanol was not always detected. Acetate could be formed as ethanol dispersed horizontally, was diluted to nontoxic levels, and fermented in the capillary fringe and/or it could be produced in the shallow groundwater. Acetate concentrations in groundwater were highly variable and ranged from below detection to approximately $3000 \mathrm{mg} / \mathrm{L}$. The variability may be a reflection of changes in recharge followed by rapid degradation. Acetate is a weak acid and a highly mobile negative ion which could easily be transported from the capillary fringe with fluctuating water tables or be produced during ethanol fermentation in the shallow groundwater. Once in groundwater, the acetate appears readily degraded by both aerobic and anaerobic organisms as it never reaches downgradient wells. The degradation of large concentrations of acetate in aerobic water would have considerable oxygen demand and tend to drive the water into an anaerobic condition. If oxygen was already depleted, the degradation then would deplete other terminal electron acceptors and fuel methanogens. Injections of acetate into groundwater rapidly denitrified nitrate within the capture zone of a municipal well (Khan and Spalding 2004). 

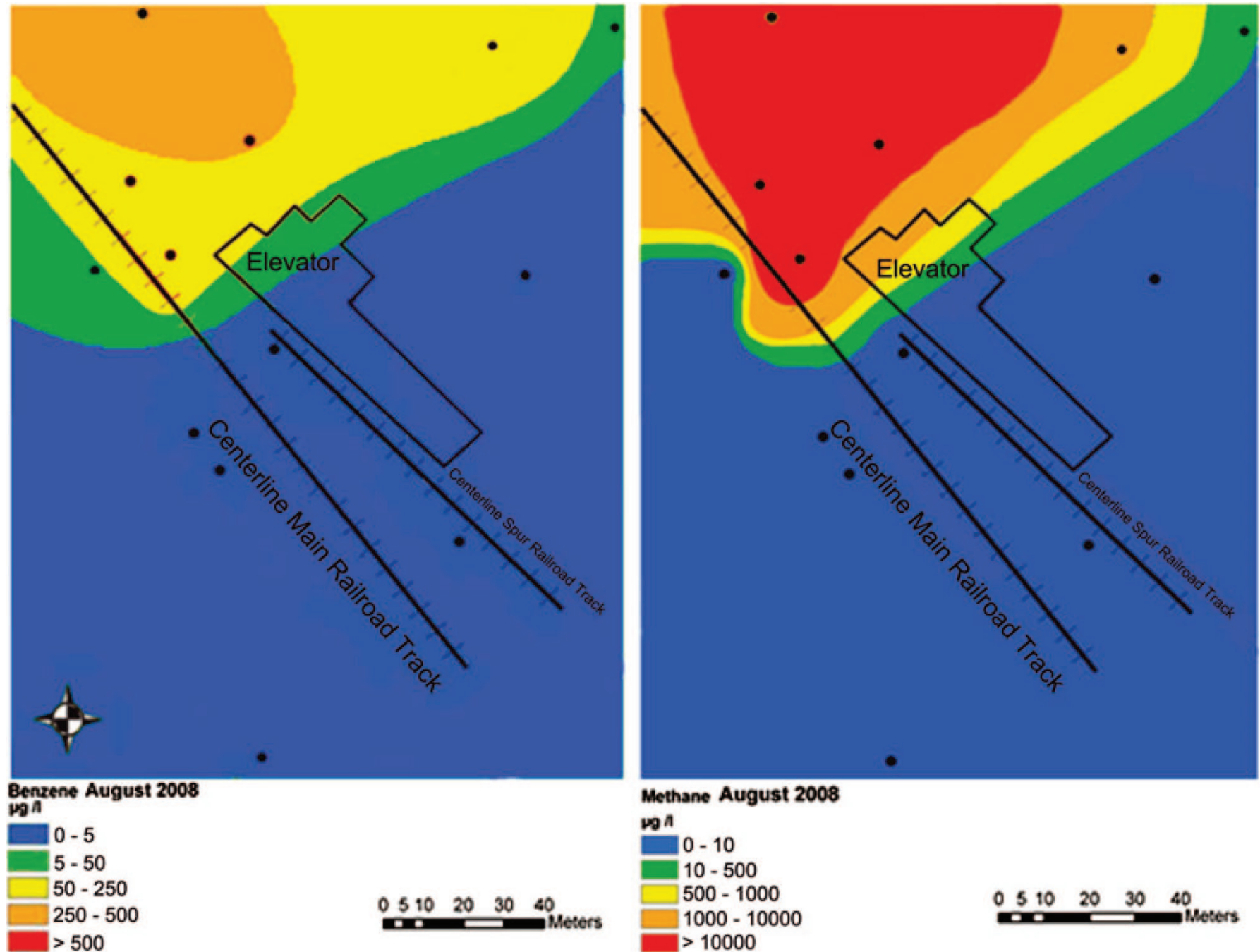

\section{Methane August 2008}

va $0-10$

$10-500$

$500-1000$

$1000-10000$

10000



Figure 8. Areal distribution of benzene and methane concentrations in the shallow groundwater at Balaton.

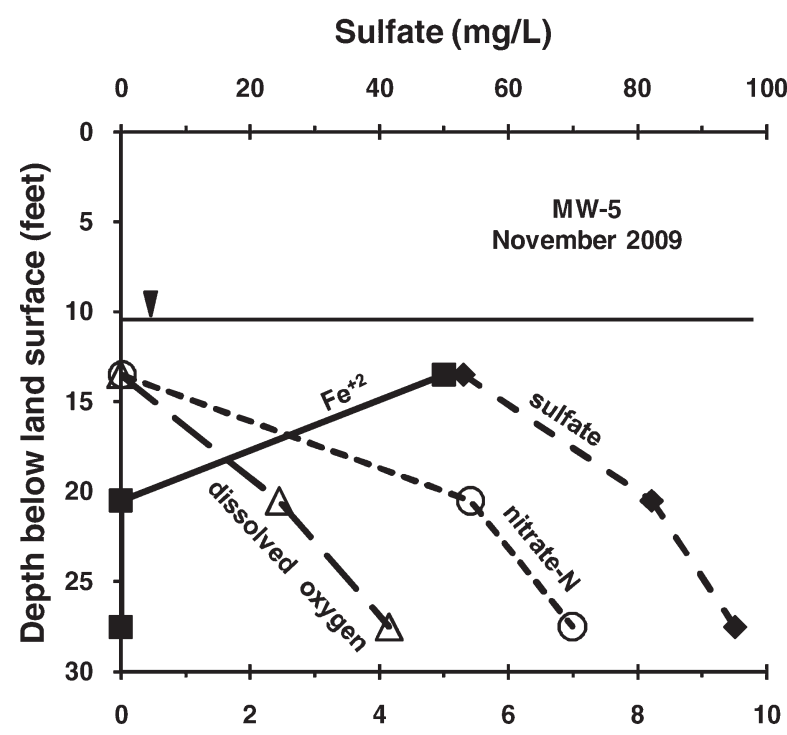

\section{Methane}

Methane is produced during the anaerobic degradation of acetate in the following net formula:

$$
\mathrm{CH}_{3} \mathrm{COOH}=\mathrm{CO}_{2}+\mathrm{CH}_{4}
$$

The detection of dissolved methane at Cambria and South Hutchinson was delayed until 1 to 2 years after the release (Figure 10). Methane concentrations were relatively stout when methane analyses began at Balaton in June 2007 and installed soil gas probes measured methane as high as $58 \%$ by volume. In June/July 2010, methane was still present in the shallow source-zone wells at all three sites. Methanogenesis occurs in soil zones with saturated or near saturated conditions. Thus, the approximately 1-year delay at Cambria likely is associated with the kinetics of the fermentation of alcohol and the proliferation of methanogens or initial ethanol concentration-induced toxicity. The 2-year delay between the release and the detection of dissolved methane at only part per million levels at South Hutchinson may have been caused by a combination of factors including the relatively slow vertical transport of ethanol to the capillary fringe of the fine-textured vadose zone and the thick capillary fringe.

Figure 9. Vertical profiles of redox indicators sulfate, nitrate, dissolved oxygen, and ferrous iron concentrations at South Hutchinson's well nest MW-5. Concentration is depicted at the mid-point of each 5-foot well screen. 


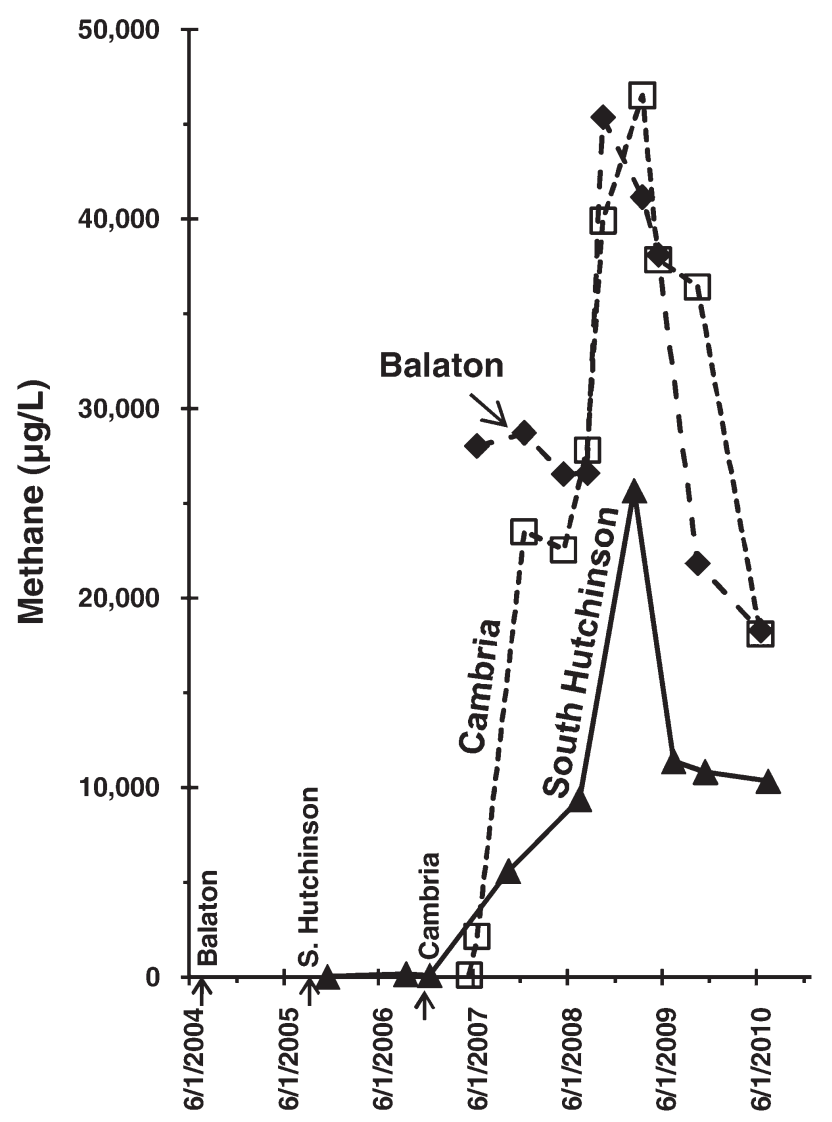

Figure 10. Temporal trend of maximum groundwater methane concentrations at the Balaton, Cambria, and South Hutchinson sites. Date of E95 release at each site is indicated on x-axis.

High methane concentrations were not limited to groundwater in the source zone and occurred in wells not directly impacted by either ethanol or acetate in the groundwater. Thus, the methane in many wells may not have been generated in groundwater as reported at another site (Mackay et al. 2006) but instead could have been generated in the capillary fringe and diffused into the groundwater. The more areally extensive impact of methane compared to that of ethanol and acetate suggests that methane is laterally transported in the lower vadose zone by gaseous diffusion and equilibrates with groundwater at the water table. At Cambria, the estimated rate of methane diffusion adjusted for the average groundwater temperature is about $3.8 \times 10^{-2} \mathrm{~m}^{2}$ / year (Broecker and Peng 1974). At South Hutchinson where the average groundwater temperature is $6.6^{\circ} \mathrm{C}$ warmer, $D=0.21 \mathrm{~m}^{2} /$ year. Stafford et al. (2009) showed that in the capillary fringe highly concentrated ethanol tends to move horizontally by advection and slowly diffuses vertically into flowing groundwater. Barber et al. (1990) reported that methane vapor was transported laterally at rates of $3.3 \mathrm{ft} / \mathrm{d}(1 \mathrm{~m} / \mathrm{d})$ and detected up to 656 feet $(200 \mathrm{~m})$ from landfilled waste. Methane concentrations in some wells exceeded its aqueous solubility $(\sim 25 \mathrm{mg} / \mathrm{L})$. At a charcoal production site in Kingsford, Michigan, the deposition of tars and wastes in glacial kettles resulted in dissolved groundwater methane levels more than $60 \mathrm{mg} / \mathrm{L}$ (Michel et al. 2001). The authors suggested that high methane levels were a result of rapid microbial degradation of a plume of VFAs. In active fermentation zones at the study sites, methane concentrations at or exceeding saturation may result from increased gas pressure due to lowered permeability from sediment biofouling. Other explanations for the persistence of ethanol and the accompanying long-term detection of high dissolved methane concentrations may be the excessive buildup of VFAs, mainly acetate. High acetate concentrations in landfills have been shown to lead to depression of $\mathrm{pH}$ and, subsequently, lowered rates of methanogenesis.

Figure 11 depicts the relationship between dissolved methane concentrations in groundwater and calculated equilibrium methane concentrations in soil gas at estimated average shallow groundwater temperatures of $7.2^{\circ} \mathrm{C}\left(45^{\circ} \mathrm{F}\right)$ and $13.9^{\circ} \mathrm{C}\left(57^{\circ} \mathrm{F}\right)$ for the Minnesota and Kansas sites, respectively. The graph indicates that many equilibrium estimates of methane soil gas concentrations in the lower vadose zone are significantly above the lower explosive limit (LEL) of 5\% methane by volume in air. Between the LEL and the 15\% upper explosive limit, methane is a potential explosion hazard if an ignition source is present. In release scenarios where nearby buildings have basements, the potential explosive hazard when methane atmospheric concentrations are between 5\% and 15\% may be a concern. In July 1995, methane that accumulated in a basement from underlying soil gas caused the explosion of a house in Kingsford, Michigan (Michel et al. 2001). Although such an occurrence is highly unlikely or close to impossible at the three derailment sites, high methane generation rates can overwhelm the available oxygen in soil gas and lead to much longer methane migration than is typically seen at gasoline release sites.

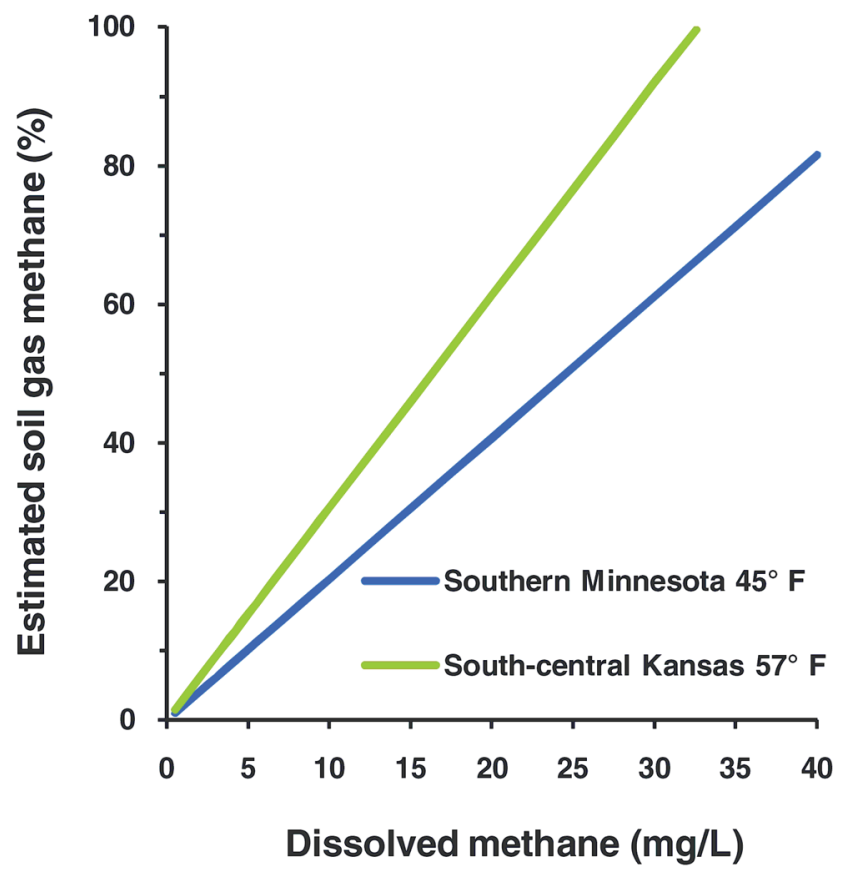

Figure 11. Estimated equilibrium relationship between dissolved methane concentrations in groundwater and soil gas concentrations using procedures of Sander (1999) and Wania et al. (2010). 


\section{Hydrogen}

Hydrogen monitoring is important as $\mathrm{H}_{2}$ levels are critical in anaerobic fermentation (Mormile et al. 1996). Owing to sampling, transport, and analytical logistics, dissolved hydrogen was monitored only at South Hutchinson. Thermodynamically, in order to maintain forward production of acetate formation from ethanol, $\mathrm{H}_{2}$ levels need to be relatively low and yet, high enough to promote $\mathrm{H}_{2}$ consumption in methanogenesis and maintain a steady state (Kramer and Conrad 1993). Thus, $\mathrm{H}_{2}$ could accumulate at levels far exceeding those consumed in methanogenesis creating an imbalance in the reaction and a delay in ethanol fermentation.

The two South Hutchinson monitoring wells (SW-7 and SW-11) with a trend of increasing ethanol concentrations also had anomalously elevated hydrogen levels. Maximum hydrogen concentrations were approximately 50 nmoles/L. No other wells in the source zone contained highly elevated hydrogen levels although concentrations in several wells ranged from 2 to 4 ๆmoles/L. The elevated hydrogen and acetate in the two wells with ethanol indicates that ethanol fermentation occurred. Hydrogen soil gas concentrations more than 100 nmoles/L have been measured in groundwater beneath landfills (Mormile et al. 1996) and were associated with a buildup of VFAs, which is in agreement with acetate concentrations as high as $450 \mathrm{mg} / \mathrm{L}$ in the South Hutchinson wells. This may explain, in part, the persistence of ethanol in the capillary fringe. Much lower dissolved hydrogen concentrations of 7 nmoles/L were reported by Chapelle et al. (1996) in heavily contaminated sediments dominated by methanogenesis at Wurtsmith Airbase, Michigan. Concentrations ranging from 5 to 15 nmoles/L suggested methanogenic-dominated conditions while much lower levels were associated with iron and sulfate reduction (Chapelle et al. 1996).

\section{Conclusions}

Although ethanol was transported to groundwater at all three sites, ethanol was not detected beyond the initial release areas. If an ethanol plume developed, it may have been limited to a thin layer at the top of the aquifer and degraded rapidly. The data do not support the contention that ethanol easily enters groundwater from the vadose zone, develops a plume, and influences the persistence of BTEX. The persistence of ethanol in the capillary fringe and/or very shallow groundwater was a surprise. The South Hutchinson core data strongly indicate that the long-term shallow groundwater contaminants did not infiltrate from the ditch where product removal and deep soil excavation occurred during the emergency response. The data show that in order to accurately monitor ethanol-blended fuel releases, short well screens should straddle the water table and capillary fringe and monitoring must be long-term. The value of monitoring terminal electron acceptors and dissolved oxygen in nested wells was demonstrated. Acetate and dissolved hydrogen concentrations provided evidence of ethanol fermentation.

Although ethanol plume elongation was not a factor, benzene persistence in the shallow groundwater could be enhanced by high dissolved methane concentrations.
Like ethanol, dissolved methane has a high oxygen demand that can retard benzene degradation. This retardation appeared restricted to shallow groundwater. Estimated soil gas methane concentrations are above the LEL at all three sites. Migration of methane from large volume, highly concentrated ethanol releases may present vapor risks for nearby subsurface confined spaces with ignitable conditions.

Interpretation of the monitoring data appears consistent with recent laboratory and field research completed at the University of Houston (Stafford 2007) and the University of Waterloo (Freitas 2009), respectively. At the behest of the reviewers, several additional hypotheses have been proposed for the preservation of ethanol in the soil, capillary zone, and shallow groundwater. Their importance in understanding the fate and transport of ethanol-based fuels should be substantiated at U.S. regulatory agency-approved controlled release sites. A full spectrum of ethanol-enriched fuels (E10 to E95) should be released. Ethanol, BTEX, their degradates, and associated analytes should be quantitatively traced using a detailed network of probes, lysimeters, and short-screened wells or multilevel samplers from controlled surface releases through the vadose zone to the groundwater.

Acknowledgments-The authors very much appreciate the financial support of the American Petroleum Institute, the Nebraska Ethanol Board, and ICM Inc. John Landwehr with Pinnacle Engineering provided valuable early information concerning the initial monitoring at the Minnesota sites. The authors would like to thank John Wilson for his considerable expertise in the analysis of trace levels of dissolved hydrogen; M. Jeff Toavs for coring and field support; and Colin Spalding for field and laboratory support. The authors especially thank Brent Stafford for his review and constructive criticisms.

\section{References}

Adamski, M., V. Kremesec, R. Kolhatkar, C. Pearson, and B. Rowan. 2005. LNAPL in fine-grained soils: Conceptualization of saturation, distribution, recovery, and their modeling. Ground Water Monitoring and Remediation 25, no. 1: 100-112.

Alvarez, P.P.J., and T.M. Vogel. 1995. Degradation of BTEX and their aerobic metabolites by indigenous microorganisms under nitrate reducing conditions. Water Science and Technology 31, no. 1: 15-28.

APHA. 1998. Standard Methods for the Examination of Water and Wastewater, 20th ed. Washington, DC, American Public Health Association.

Barber, C., G.B. Davis, D. Briegel, and J.K. Ward. 1990. Factors controlling the concentration of methane and other volatiles in groundwater and soil-gas around a waste site. Journal of Contaminant Hydrology 5, no. 2: 155-169.

Bashir, R., J.E. Smith, and D.F. Stolle. 2008. Surfactant-induced unsaturated flow: Instrumented horizontal flow experiment and hysteretic modeling. Soil Science Society of America Journal 72, no. 6: 1510-1519.

Broecker, W.S. and T.-H. Peng. 1974. Gas exchange rates between air and sea. Tellus 26, no. 1-2: 21-35.

Buscheck, T.E., K.T. O'Reilly, G. Koschal, and G. O'Regan. 2001. Ethanol in groundwater at a Pacific Northwest ter- 
minal. In Proceedings of the Petroleum Hydrocarbons and Organic Chemicals in Groundwater Conference, November 14-16, Houston, Texas and Dublin, Ohio: Groundwater Publishing Co.

Cápiro, N.L., B.P. Stafford, W.G. Rixey, P.B. Bedient, and P.P.J. Alvarez. 2007. Fuel-grade ethanol transport and impacts to groundwater in a pilot-scale aquifer tank. Water Research 41, no. 3: 656-664.

Chapelle, F.H., D.A. Vroblesky, J.C. Woodward, and D.R. Lovley. 1997. Practical considerations for measuring hydrogen concentrations in groundwater. Environmental Science and Technology 31, no. 10: 2873-2877.

Chapelle, F.H., S.K. Haack, P. Adriaens, M.A. Henry, and P.M. Bradley. 1996. Comparison of Eh and H2 measurements for delineating redox processes in a contaminated aquifer. Environmental Science and Technology 30, no. 12: 3565-3569.

Chen, Y.D., J.F. Barker, and L. Gui. 2008. A strategy for aromatic hydrocarbon bioremediation under anaerobic conditions and the impacts of ethanol: A microcosm study. Journal of Contaminant Hydrology 96, no. 1-4: 17-31.

Constantin, H., and M. Fick. 1997. Influence of C-sources on the denitrification rate of a high-nitrate concentrated industrial wastewater. Water Research 31, no. 3: 583-589.

Corseuil, H.X., M. Fernandes, M. do Rosário, and P.N. Seabra. 2000. Results of a natural attenuation field experiment for an ethanol-blended gasoline spill. In Proceedings of NGWA/ API Conference and Exposition on Petroleum and Organic Chemicals in Ground Water: Prevention, Detection, and Remediation, November 15-17, Anaheim, California, and Dublin, Ohio: Groundwater Publishing Co.

Corseuil, H.X., C.S. Hunt, R.C. Ferreira dos Santos, and P.J.J. Alvarez 1998. The influence of the gasoline oxygenate ethanol on aerobic and anaerobic BTX biodegradation. Water Research 32, no. 7: 2065-2072.

Deeb, R.A., J.O. Sharp, A. Stocking, S. McDonald, K.A. West, M. Laugier, P.J.J. Alvarez, M.C. Kavanaugh, and L. Alvarez- Cohen. 2002. Impact of ethanol on benzene plume lengths: Microbial and modeling studies. Journal of Environmental Engineering 128, no. 9: 868-875.

Energy Institute. 2008. EI literature Review: Biofuels - Potential Risks to UK Water Resources. London, UK: Energy Institute.

Freitas, J.G. 2009. Impacts of ethanol in gasoline on subsurface contamination. Ph.D. dissertation, Earth Science Department, University of Waterloo.

Freitas, J.G., M.T. Mocanu, J.L.G. Zoby, J.W. Molson, and J.F. Barker. 2011. Migration and fate of ethanol-enhanced gasoline in groundwater: A modelling analysis of a field experiment. Journal of Contaminant Hydrology 119, no. 1-4: 25-43.

Ghose, T.K., and A. Bhadra. 1985. Acetic acid. In Comprehensive Biotechnology, The Practice of Biotechnology: Current Commodity Products, ed. M. Moo-Young, H.W. Blanch, S. Drew, and D.I.C. Wang. Vol. 3, 701-729. London, UK: Pergamon Press.

Heermann, S.E., and S.E. Powers. 1998. Modeling the partitioning of BTEX in water-formulated gasoline systems containing ethanol. Journal of Contaminant Hydrology 34, no. 4: 315-341.

Hunt, C.S., P.J.J. Alvarez, R.C. Ferreira dos Santos, and H.X. Corseuil. 1997. Effect of ethanol on aerobic BTEX degradation. In In Situ and On-Site Bioremediation, ed. B.C. Alleman and A.L. Leeson. Vol. 4, no. 1: 49-54. Columbus, Ohio: Battelle Press.

Interstate Technology and Regulatory Council. 2007. Vapor intrusion pathway: A practical guideline. ITRC Technical Regulatory Guidance document. Washington, DC.
Kampbell, D.H., and S.A. Vandegrift. 1998. Analysis of dissolved methane, ethane, and ethylene in ground water by a standard gas chromatographic technique. Journal of Chromatographic Science 36, no. 5: 253-256.

Khan, I.A., and R.F. Spalding. 2004. Enhanced in situ denitrification for a municipal well. Water Research 38, no. 14-15: 3382-3388.

Khan, I.A., and R.F. Spalding. 2003. Development of a procedure for sustainable in-situ aquifer denitrification. Remediation 13, no. 2: 53-69.

Kramer, H., and R. Conrad. 1993. Measurement of dissolved $\mathrm{H} 2$ concentrations in methanogenic environments with a gas diffusion probe. FEMS Microbiology Ecology 12, no. 3 : 149-158.

Leonard, R.A., and W.A. Jackson. 1975. Dispersion of clays in ethanol solutions. Soil Science of America Journal 39, no. 6: 1215-1217.

Lovley, D.R. 2000. Anaerobic benzene degradation. Biodegradation 11, no. 2-3: 107-116.

Mackay, D.M., N.R. de Sieyes, M.D. Einarson, K.P. Feris, A.A. Pappas, I.A. Wood, L. Jacobson, L.G. Justice, M.N. Noske, K.M. Scow, and J.T.Wilson. 2006. Impact of ethanol on the natural attenuation of benzene, toluene, and o-xylene in a normally sulfate-reducing aquifer. Environmental Science and Technology 40, no. 19: 6123-6130.

McDowell, C.J., and S.E. Powers. 2003. Mechanisms affecting the infiltration and distribution of ethanol-blended gasoline in the vadose zone. Environmental Science and Technology 37, no. 9: 1803-1810.

McDowell, C.J., T. Buscheck, and S.E. Powers. 2003. Behavior of gasoline pools following a denatured ethanol spill. Ground Water 41, no. 6: 746-757.

McInnes, D.M., and D. Kampbell. 2003. Bubble stripping to determine hydrogen concentrations in ground water: a practical application of Henry's Law. Journal of Chemical Education 80, no. 5: 516-519.

McNab, W., S.E. Heermann, and B. Dooher. 1999. Screening model evaluation of the effects of ethanol on benzene plume lengths. In Health and Environmental Assessment of the Use of Ethanol as a Fuel Oxygenate, ed. D.W. Rice and G. Cannon. Vol. 4, ch. 2. California State Water Resources Control Board Report UCRL-AR-135949, Livermore, California: Lawrence Livermore National Laboratory.

Michel, R.L., S.R. Silva, B. Bemis, E.M. Godsy, and E. Warren. 2001. Compound-specific carbon isotope analysis of a contaminant plume in Kingsford, Michigan, USA. In Impact of Human Activity on Groundwater Dynamics. International Association of Hydrological Sciences pub. no. 269: 311-316.

Molson, J.W., J.F. Barker, E.O. Frind, and M. Schirmer. 2002. Modeling the impact of ethanol on the persistence of benzene in gasoline-contaminated groundwater. Water Resources Research 38, no. 1: 4-1-4-12.

Mormile, M.R., K.R. Gurijala, J.A. Robinson, M.J. McInerney, and J.M. Suflita. 1996. The importance of hydrogen in landfill fermentations. Applied and Environmental Microbiology 62, no. 5: 1583-1588.

Nelson, D.K., T.M. Lapara, and P.J. Novak. 2010. Effects of ethanol- based fuel contamination: microbial community changes, production of regulated compounds, and methane generation. Environmental Science and Technology 44, no. 12: $4525-4530$.

Pew Center on Global Climate Change. 2010. http://www. pewclimate.org/what s being done/in the states/map ethanol.cfm (accessed October 22, 2010). 
Pinnacle Engineering, Inc. 2007. Summary Report Initial Investigation for DMEE Railroad Ethanol Release, Cambria, Minnesota. Maple Grove, Minnesota: Pinnacle Engineering, Inc., February 14, 2007.

Pinnacle Engineering, Inc. 2006. Additional Investigation Report for DMEE Railroad Release, Balaton, Minnesota. Maple Grove, Minnesota: Pinnacle Engineering, Inc., March 31, 2006.

Pinnacle Engineering, Inc. 2004a. Excavation Results/Investigation Work Plan for DMEE Railroad Release, Balaton, Minnesota. Osseo, Minnesota: Pinnacle Engineering, Inc., September 15, 2004.

Pinnacle Engineering, Inc. 2004b. Site Investigation Report for DMEE Railroad Release, Balaton, Minnesota. Maple Grove, Minnesota: Pinnacle Engineering, Inc., December 5, 2004.

Powers, S.E., C.S. Hunt, S.E. Heermann, H.X. Corseuil, D. Rice, and P.J.J. Alvarez. 2001. The transport and fate of ethanol and BTEX in groundwater contaminated by gasohol. Critical Reviews in Environmental Science and Technology 31, no. 1: 79-123.

Rao, P.S.C., M.D. Annable, R.K. Sillan, D. Dai, K. Hatfield, and W.D. Graham. 1997. Field-scale evaluation of in situ cosolvent flushing for enhanced aquifer remediation. Water Resources Research 33, no. 12: 2673-2686.

Rixey, W.G., X. He, and B.P. Stafford. 2005. The impact of gasohol and fuel-grade ethanol on BTX and other hydrocarbons in ground water: Effect on concentrations near a source. American Petroleum Institute Technical Publication No. 23.

Ruiz-Aguilar, G.M.L., K. O’Reilly, and P.J.J. Alvarez. 2003. A comparison of benzene and toluene plume lengths for sites contaminated with regular vs. ethanol-amended gasoline. Ground Water Monitoring and Remediation 23, no. 1: 48-53.

Sander, R. 1999. Modeling atmospheric chemistry: Interactions between gas-phase species and liquid cloud/aerosol particles. Surveys in Geophysics 20, no. 1: 1-31.

Smith, J.E., and R.W. Gillham. 1999. Effects of solute concentration- dependent surface tension on unsaturated flow: Laboratory sand column experiments. Water Resources Research 35, no. 4: 973-982.

Stafford, B.P. 2007. Impacts to groundwater from releases of fuel grade ethanol: Source behavior. Ph.D. dissertation, Department of Civil and Environmental Engineering, University of Houston.

Stafford, B.P., and W.G. Rixey. 2011. Distribution of fuel grade ethanol near a dynamic water table. Ground Water Monitoring and Remediation. In press.

Stafford, B.P., N.L. Cápiro, P.J.J. Alvarez, and W.G. Rixey. 2009. Pore water characteristics following a release of neat ethanol onto pre-existing NAPL. Ground Water Monitoring and Remediation 29, no. 3: 93-104.

Vandevivere, P., and P. Baveye. 1992. Effect of bacterial extracellular polymers on the saturated hydraulic conductivity of sand columns. Applied Environmental Microbiology 58, no. 5: 1690-1698.

Wania, R., I. Ross, and I.C. Prentice. 2010. Implementation and evaluation of a new methane model within a dynamic global vegetation model. Geoscientific Model Development Discussions 3: 1-59.

Zhang, Y., I.A. Khan, and R.F. Spalding. 2006. Transport and degradation of ethanol in groundwater. Journal of Contaminant Hydrology 82, no. 3-4: 183-194.

\section{The Authors}

Roy F. Spalding, corresponding author, is a professor at the Department of Agronomy and Horticulture, University of Nebraska-Lincoln, 279 Plant Science Hall, Lincoln, NE 68583-0915; (402) 472-8214; rspalding1@unl.edu

Mark A. Toso is a senior hydrogeologist at the Minnesota Pollution Control Agency, St. Paul, MN 55155.

Mary E. Exner is a professor at the School of Natural Resources, University of Nebraska-Lincoln, Lincoln, NE 68583.

Gregory Hattan, formerly unit chief, UST remediation group at the Kansas Department of Health and the Environment, Topeka, KS, is now with the U.S. Army Corps of Engineers, Kansas City District, MO.

Tom M. Higgins is a hydrologist at the Minnesota Pollution Control Agency, St. Paul, MN 55155.

Adam C. Sekely is a hydrologist at the Minnesota Pollution Control Agency, Baxter, MN 56425.

Shane D. Jensen formerly was a research technologist at the Department of Agronomy and Horticulture, University of Nebraska-Lincoln, Lincoln, NE 68583. 